\title{
REVIEW
}

\section{The emerging role of Twist proteins in hematopoietic cells and hematological malignancies}

\author{
This article has been corrected since Online Publication and a corrigendum has also been published
}

N Merindol ${ }^{1}$, A Riquet ${ }^{1}$, V Szablewski ${ }^{2,3}$, J-F Eliaou ${ }^{2,4}$, A Puisieux $^{5}$ and N Bonnefoy ${ }^{2}$

Twist1 and Twist2 (Twist1-2) are two transcription factors, members of the basic helix-loop-helix family, that have been well established as master transcriptional regulators of embryogenesis and developmental programs of mesenchymal cell lineages. Their role in oncogenesis in epithelium-derived cancer and in epithelial-to-mesenchymal transition has also been thoroughly characterized. Recently, emerging evidence also suggests a key role for Twist1-2 in the function and development of hematopoietic cells, as well as in survival and development of numerous hematological malignancies. In this review, we summarize the latest data that depict the role of Twist1-2 in monocytes, T cells and B lymphocyte activation, and in associated hematological malignancies.

Blood Cancer Journal (2014) 4, e206; doi:10.1038/bcj.2014.22; published online 25 April 2014

\section{INTRODUCTION}

Twist1-2 main functions

Twist1 and Twist2 (Twist1-2) are two distinct tissue-restricted transcription factor members of the basic helix-loop-helix (bHLH) class B family that display high sequence similarity with each other. They play a critical role in embryogenesis, particularly in the inhibition of mesenchymal cell development. In humans, mutations in twist 1 cause the Saethre-Chotzen syndrome, an autosomal dominant inheritance disease principally characterized by craniosynostosis (premature closure of clavarial suture). ${ }^{1,2}$ Heterozygous twist $1^{+1-}$ mice show craniofacial and limb abnormalities, whereas twist $^{\text {ko }}$ mice die early during embryogenesis. Twist2 is expressed after Twist1 in mesodermal tissues during embryogenesis. Twist2 inhibits terminal differentiation of mesoderm-derived cells, such as myocytes, osteoblasts and adipocytes. ${ }^{3-6}$ In humans, mutations in twist2 are associated with the Setleis Syndrome, an inherited developmental disorder characterized by bilateral temporal marks and other facial features. ${ }^{7}$ Twist $2^{\mathrm{ko}}$ mice exhibit normal embryogenesis but die 2-3 days after birth of generalized cachexia caused by high levels of proinflammatory cytokines. ${ }^{8}$

\section{A complex regulation}

The expression of Twist1-2 is triggered by diverse signaling pathways linked to inflammatory-related cytokines via nuclear factor (NF)- $\kappa B^{8,9}$ and signal transducer and activator of transcription 3 (STAT3), ${ }^{10}$ and to stress conditions via WNT/ $\beta$ catenin $^{11}$ and hypoxia-inducible factor-1. ${ }^{2,13}$ As described throughout this review, their expression is tightly regulated, context dependent and multifactorial.

To confuse the situation, once expressed, Twist1-2 may function either as transcriptional activators or repressors, through both direct and indirect mechanisms. ${ }^{14-16}$ They act through direct mechanisms when they bind to conserved DNA E-box sequences $\left(5^{\prime}\right.$-NCANNTGN-3') present in the regulatory region of many lineage-specific genes ${ }^{17}$ and function as transcription factors (Figure 1); through indirect mechanisms when they activate/ repress gene expression via recruitment of co-activators/repressors at the E-boxes they are bound to, or when they associate with other transcription factors such as MEF2, RUNX1, RUNX2, CEBP- $\alpha$ and NF- $\kappa$ B to modulate gene transcription ${ }^{5,8,18,19}$ (Figure 1).

Mechanisms that influence transcription regulation by Twist1-2 include (1) their spatial and temporal regulation, (2) their posttranslational modifications (acetylation and phosphorylation), (3) their dimer choice, (4) their affinity with potential dimers and (5) protein-protein interactions (Figure 1).

The most characterized post-translational modification of Twist1 is its phosphorylation on serine 68 (S68) by mitogen-activated protein kinases such as p38, c-Jun N-terminal kinase and extracellular signal-regulated kinase-1/2. ${ }^{20,21} \mathrm{~S} 68$ phosphorylation inhibits ubiquitylation-mediated degradation of Twist1 and thus regulates its half-life and availability. PKA (protein kinase A), PKC, PKB/Akt and PP2 can all modulate Twist1 phosphorylation levels at several other amino acid positions..$^{20,22-24}$

Twist1-2 can also influence gene transcription through epigenetic modulation of the promoter region. Indeed, Twist1-2 were reported to interact with and recruit histone acetyl transferases/histone deacetylases to the promoter regulatory region that results in transcription repression through histone modification $^{4,14,15}$ (Figure 1).

Twist1-2 may form homodimers and heterodimers with class A bHLH ${ }^{5,25}$ E protein transcription factors or E2A that contain both E12 and E47-Tcf3 and are implicated in immune cell development. ${ }^{26}$ Twist 1-2 partner choice depends mostly on its accessibility and on Twist1-2 phosphorylation acetylation

\footnotetext{
${ }^{1}$ Université de Lyon and INSERM U1111, Lyon, France; ${ }^{2}$ IRCM, Institut de Recherche en Cancérologie de Montpellier, INSERM U896, Université Montpellier 1, Montpellier, France; ${ }^{3}$ Département de Biopathologie, Centre Hospitalier Régional Universitaire de Montpellier et Faculté de Médecine, Université Montpellier 1 , Montpellier, France; ${ }^{4}$ Département d'Immunologie, Centre Hospitalier Régional Universitaire de Montpellier et Faculté de Médecine, Université Montpellier 1, Montpellier, France and ${ }^{5}$ Centre de Receherche en Cancérologie de Lyon, INSERM UMR-S1052, Centre Léon Bérard, Lyon, France. Correspondence: Dr N Merindol, Department of Medical Biology, UQTR, 3351 Boulevard des Forges, Trois-Rivieres, QC G9A5H7, Canada or Dr N Bonnefoy, Institut de Recherche en Cancérologie de Montpellier, 208 rue des Apothicaires, Montpellier, F-34298, France. E-mail: natachamerindol@yahoo.ca or nathalie.bonnefoy@inserm.fr

Received 25 February 2014; accepted 17 March 2014
} 


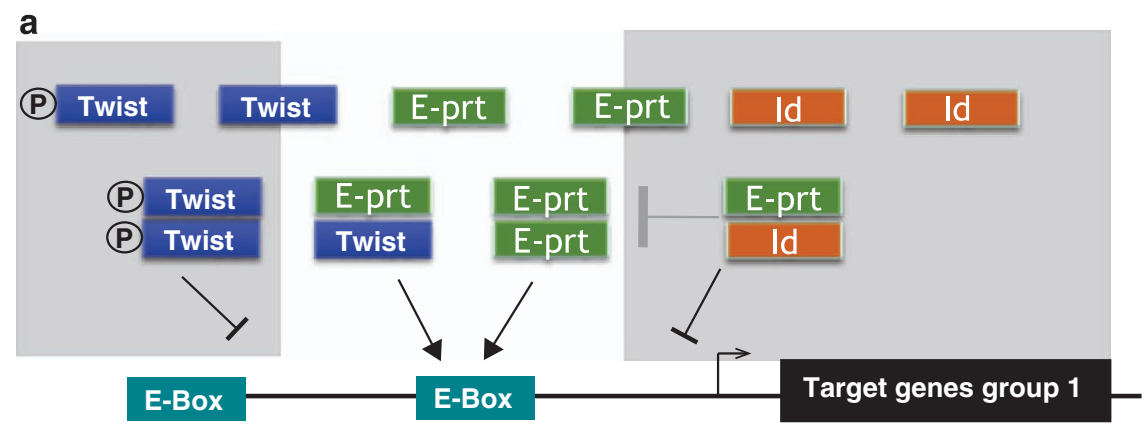

b

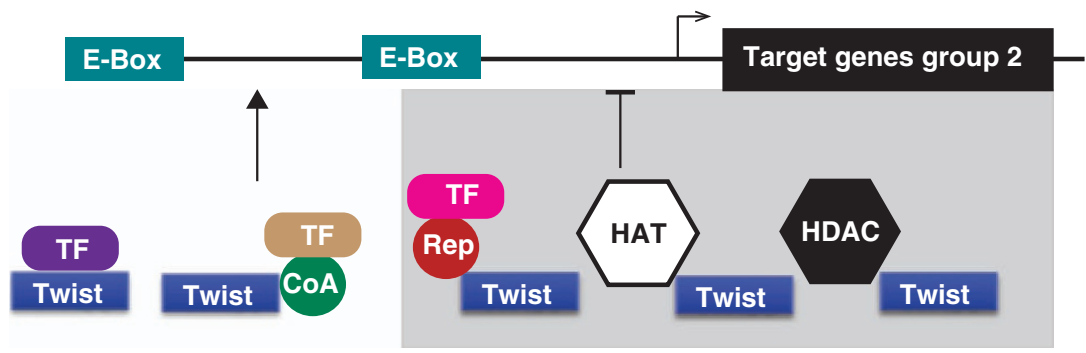

Figure 1. Transcriptional regulation by Twist proteins. (a) The bHLH partner competition. Twist1-2 might act directly as transcription factors through binding to E-boxes $\left(5^{\prime}\right.$-NCANNTGN-3') in the promoter regulatory region of multiple lineage-specific genes. They may form homodimers and heterodimers with class A bHLH transcription factor E proteins (E12 and E47). Twist1-2 partner choice depends mostly on their accessibility and on Twist1-2 phosphorylation status. Availability of E proteins is determined by their level of expression and by the presence of Id (inhibition of DNA binding) proteins (Id1, Id2, Id3 and Id4) that lack a DNA-binding domain. The relative stoichiometry of each participant will define partner choice that, in turn, will determine the scheme of gene targeting. E-prt, E proteins; Twist; Twist1 or Twist2. (b) Pathways of transcriptional regulation. Twist1-2 might also activate gene expression through direct interaction with transcription factors (such as MEF2, RUNX1, RUNX2, CEBP- $\alpha$ and NF- $\mathrm{kB}$ ) and co-activators of transcription factors. They can inhibit transcription through direct interaction and sequestration of transcription factors, their repressors or through epigenetic modulation by recruitment of histone acetyltransferase and histone deacetylase at the promoter region. CoA, co-activator; HAT, histone acetyltransferase; HDAC, histone deacetylase; Rep, repressor; TF, transcription factors.

state ${ }^{23,27}$ and this choice of partner will determine which genes are transcriptionally targeted (Figure 1). Availability of E proteins is not only determined by their expression but also by the presence of a third class of bHLH proteins that lack the DNA-binding domain: namely Id (inhibition of DNA binding) proteins (Id1, Id2, Id3 and Id4). They display great affinity for E2A proteins, in particular for E12, and therefore limit its availability, alter the possible dimerization pools, prevent its DNA binding and compete against Twist $1-2^{27,28}$ (Figure 1). The formation of Twist1/E47 heterodimers seems to stabilize Twist1, whereas detection of Twist1/ld1 heterodimers has been associated with destabilization and degradation of Twist1. ${ }^{29}$ Twist1-2 also modulate the expression of $E$ protein-dependent genes by sequestrating E-protein modulators. Ultimately, the relative stoichiometry of each $E$ protein, Id repressors and Twist1-2 will determine the expression profile and cell fate, that is, homodimers of Twist will be preferentially found when Id proteins sequestrate E12 (Figure 1). Finally, in 2010, Danciu and Whitman ${ }^{30}$ proposed that the redox state of the cell is also involved in transcriptional outcome by stabilizing disulphide bonds between Twist1-2 homodimers and thus preventing heterodimer formation.

\section{A major role for Twist1-2 in regulating inflammation}

The perinatal death due to high levels of proinflammatory cytokines of mice with a twist $2^{k 0}$ genotype or carrying twist 1 and twist2 haploinsufficiency hints at a key role for Twist1-2 in the control of proinflammatory response, and illustrates the complexity of the transcriptional regulation mechanisms by and of Twist1-2. On one hand, they both regulate proinflammatory cytokine expression by interfering with NF- $\kappa B$-dependent gene

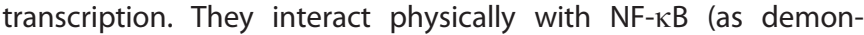
strated for Twist1 in COS cells), and bind to E-boxes in the regulatory regions of $\mathrm{NF}-\kappa \mathrm{B}-$-regulated cytokines, such as tumor necrosis factor- $\alpha$ (TNF $\alpha$ ) and interleukin (IL)- $1 \beta$, as shown in murine macrophages ${ }^{8}$ (Figure 1 ). Furthermore, Twist2 is able to inhibit IL12 and interferon- $\gamma$ (IFN $\gamma$ ) expression and to activate the production of the anti-inflammatory cytokine IL-10, ${ }^{31}$ whereas upon phosphorylation on S42 by PKB/Akt, Twist1 is able to enhance anti-inflammatory TGF $\beta$ receptor signaling. ${ }^{21}$

On the other hand, Twist1-2 expression itself is activated by $\mathrm{NF}-\kappa \mathrm{B}$, suggesting the existence of a negative feedback loop where NF- $\mathrm{BB}$ pro- and anti-apoptotic pathways are activated by cytokines (such as TNF $\alpha$ ), leading to downstream activation of other cytokines and of Twist1-2. In turn, Twist1-2 interact with p65/RelA subunit of NF- $\kappa B$, causing the repression of NF- $\kappa B$ mediated transactivation of cytokines. ${ }^{8}$ Their activation and interaction by and with NF- $\mathrm{KB}$ is conserved across species. This negative feedback loop sets Twist1-2 as central modulators of the NF- $\kappa \mathrm{B}$ proinflammatory pathway.

Finally, their role in the proinflammatory response incidentally implicates Twist1-2 in the modulation of the immune system response. Indeed, recent studies show their considerable role in immune cell function. Moreover, dysregulation of Twist1 or Twist2 are implicated in the pathogenesis of various hematological malignancies. $^{31-33}$

\section{FUNCTIONS OF TWIST1-2 IN HEMATOPOIETIC LINEAGES} Myeloid lineage

In the hematopoietic system, the expression of Twist 1 is largely observed in $\mathrm{CD}_{34}{ }^{+}$hematopoietic stem cells, ${ }^{34-36}$ whereas Twist2 is mostly expressed in the myeloid lineage. ${ }^{31}$ Twist2 is a major negative modulator of both the development of myeloid cells and their proinflammatory responses. It is expressed in granulocytemacrophage progenitors, and inhibits their proliferation and differentiation into macrophages, neutrophils and basophils, 
through direct interaction and inhibition of RUNX1 and C/EBP $\alpha$ transcription factors. ${ }^{31}$ In mature myeloid cells, Twist2 negatively regulates the proinflammatory responses by inhibiting the expression of proinflammatory cytokines such as IL12, IFN $\gamma$, IL1, TNF $\alpha$, IL6, mococyte chemoattractant protein- 1 and macrophage inflammatory protein- $1 \alpha$ through inactivation of $C / E B P \alpha$ and NF- $\mathrm{KB}$, while activating anti-inflammatory IL10 expression ${ }^{31}$; (Table 1).

In murine mature macrophages, Twist1-2 are also implicated in an anti-inflammatory feedback loop triggered by IFN $\alpha$ to counteract production of TNF $\alpha^{33}$ Indeed, IFN type I strongly induced (1) mRNA and protein expression of Twist1-2 through induction of the receptor tyrosine kinase Axl, (2) responsiveness to Axl ligands and (3) concomitant reduction of TNF $\alpha$ expression. Sharif et al. $^{33}$ showed evidence that suppression of TNF $\alpha$ expression was mediated in part by Twist1-2 binding to E-boxes in the TNF $\alpha$ promoter region. Twist $1-2$ also modulate the function of several other transcription factors expressed in macrophages such as E-proteins, myocyte enhancer factor 2 (MEF2) and sterol regulatory element-binding protein-1 (SREBP1), positioning them as central in the regulation of macrophage priming and antiinflammatory response. ${ }^{4,5,18,37}$

Although its precise role is still unknown, Twist1 is also expressed in follicular dendritic cells that are specialized mesenchymal-derived stromal cells found in the germinal centers of lymphoid tissues that trap and present immune complexes to $B$ cells, enabling their maturation. ${ }^{37}$

\section{Lymphoid lineage}

$T$ lymphocytes. The $\mathrm{T}$ lymphocyte family encompasses $\mathrm{CD} 8^{+}$ $\mathrm{T}$ lymphocytes that are cytolytic effector cells, $\mathrm{CD} 4^{+}$helper $\mathrm{T}$ cells whose role is auxiliary to other immune cells, and CD4 ${ }^{+}$ regulatory $T$ cells. $T$ cells are further differentiated into naive, effector memory (EM), central memory (CM) and terminally differentiated effector memory phenotypes depending on their exposure to and activation by their antigen (reviewed in Appay et $\left.a \beta^{38}\right) . C D 4^{+}$helper $T$ lymphocytes are also divided in different subsets that display different functions. The best characterized includes $T$ helper $1\left(T_{H} 1\right)$ and $T$ helper $2\left(T_{H} 2\right)$, and other subsets such as $T$ helper $17\left(T_{H} 17\right)$, follicular helper $T$ cells $\left(T F_{H}\right)$ and the more recently described T helper $9\left(T_{H} 9\right)$ (reviewed in Wan et a ${ }^{39}$ ).

There are ever-increasing data aiming to decipher the role of Twist1-2 in the T-cell response. These studies seem to suggest that, in this context, Twist1-2 display different and nonredundant functions.

Twist1 and $T$ lymphocytes. In 2008, Niesner et al. ${ }^{40}$ were the first to identify Twist1 as a key modulator of $T_{H} 1$ lymphocyte proinflammatory response in mice. They observed that Twist1 expression was predominant in differentiated $T_{H} 1$ effector memory cells. Accordingly, Twist1 expression was transiently induced following $T$ cell receptor stimulation through NFAT (nuclear factor of activated $\mathrm{T}$ cells) and NF- $\mathrm{KB}$, then enhanced and constantly detected upon repeated $T$ cell receptor stimulations. Its expression was also activated by IL12 via STAT4. Following activation of naive $\mathrm{T}_{\mathrm{H}} 1$ cells, NFAT, NF-KB and STAT4 had to be bound to their respective binding sites in the promoter region of twist1 to induce its transcription, whereas in activated $\mathrm{T}_{\mathrm{H}} 1$ cells, NFAT and NF- $\kappa B$ binding to the twist1 promoter region was sufficient to trigger its expression. Ex vivo, Twist1 expression was mostly observed in memory $\mathrm{CD}^{+}{ }^{+} \mathrm{T}$ cells and was especially high in chronically activated $\mathrm{CD}^{+} \mathrm{T}$ cells. Furthermore, the authors described that ectopic overexpression of Twist 1 in 6-day-old $T_{H} 1$ cells drastically reduced their pathogenic contribution in inflammation, whereas Twist1 silencing enhanced their potential to induce chronic inflammation. These results imply a key role for Twist1 in limiting inflammation in $\mathrm{T}_{H} 1$ cells. In T cells, as in macrophages, Twist1-mediated repression of NF- $\kappa B$-activated pathways seems to act through binding to E-boxes in regulatory regions of NF- $\kappa B$ target genes. In particular, Twist1 appeared to dampen inflammation triggered by $T_{H} 1$ memory cells in

Table 1. Functions of Twist1 and Twist2 in hematopoietic cells

\begin{tabular}{|c|c|c|}
\hline Myeloid lineage: & $\begin{array}{l}\text { - Key regulators of priming and of the anti-inflammatory } \\
\text { response of macrophages } \\
\text { Mediators of an anti-inflammatory feedback loop } \\
\text { triggered in response to IFN } \alpha \text { through AxI to counteract } \\
\text { TNF } \alpha \text { production. }{ }^{33} \\
\text { Modulation of E-proteins, MEF } 2 \text { and SREBP1 } 1,5,19,37 \\
\text { - Expressed in follicular dendritic cells (unknown } \\
\text { function). }{ }^{37}\end{array}$ & $\begin{array}{l}\text { - Expressed in myeloid progenitors. } \\
\text { Inhibition of proliferation and differentiation into macrophages, } \\
\text { neutrophils, basophils through inhibition of RUNX1 and C/EBP } \alpha .{ }^{31} \\
\text { - Expressed in mature myeloid cells. } \\
\text { Negative regulation of the proinflammatory response: activation } \\
\text { of IL-10, inhibition of IL } 12, \text { IFN } \gamma \text {, IL } 1, \mathrm{TNF} \alpha, \text { IL } 6, \mathrm{MCP} 1 \text { and MIP } 1 \alpha \\
\text { through inactivation of } \mathrm{C} / \mathrm{EBP} \alpha \text { and NF- } \mathrm{B} B{ }^{31}\end{array}$ \\
\hline T lymphocytes & $\begin{array}{l}\text { - Expressed mainly in } \mathrm{T}_{\mathrm{H}} 1 \text { lymphocytes } \\
\text { Induction by TCR stimulation through NFAT and NF- } \mathrm{KB} \text {, } \\
\text { by IL12 via STAT4 } 4^{40} \\
\text { Prevention of chronic inflammation }{ }^{40,42,43} \\
\text { Inhibition of the proinflammatory response. } \\
\text { Repression of NF- } \mathrm{kB} \text { activated pathways, TNF } \alpha \text {, IL2, } \\
\text { SOCS1, SOCS2, IL1R decoy and Jak2. }{ }^{40} \\
\text { Inhibition of IFN- } \gamma \text { through modulation of T-bet, STAT4 } \\
\text { and RUNX3. }{ }^{41} \\
- \text { Inhibition of } \mathrm{T}_{\mathrm{H}} 17 \text { polarization and T follicular helper } \\
\text { development }{ }^{43} \\
\text { Induced by STAT3 to control IL6 signaling }\end{array}$ & $\begin{array}{l}\text { - Expressed in thymocytes and mature T lymphocytes } \\
\text { Prevention of galectin-1 mediated apoptosis after NF-אB } \\
\text { activation during negative selection. }{ }^{19,32}\end{array}$ \\
\hline B lymphocytes & NA & Expressed in B cells (unknown function). ${ }^{45}$ \\
\hline
\end{tabular}


mice experiencing delayed-type hypersensitivity and antigeninduced arthritis through the specific targeting of TNF $\alpha$, IL2, IFN $\gamma$, SOCS1, SOCS2, IL1R decoy and Jak2. Interestingly, and in contrast to the well-known properties of Twist 1 in the induction of the epithelial-to-mesenchymal transition (EMT), ${ }^{41}$ Twist1 expression did not interfere with the homing capacity of $T_{H} 1$ cells to the inflamed tissue.

The authors further validated their results in humans, showing that expression of Twist 1 was low in naive $\mathrm{CD}^{+}{ }^{+} \mathrm{T}$ cells, enhanced in activated effector memory $\mathrm{CD}^{+}{ }^{+} \mathrm{T}$ cells and even higher in terminally differentiated effector memory $\mathrm{CD}^{+}{ }^{+} \mathrm{T}$ cells. ${ }^{40}$ Twist1-expressing $\mathrm{CD} 4{ }^{+} \mathrm{T}$ cells exhibited the phenotype of activated $T_{H} 1$ effector memory cells (CD45RA ${ }^{-}$CCR7 ${ }^{-}$CD $27^{+1}$

and $\mathrm{CCR5}^{+}$). Interestingly, they also show that Twist1 expression was upregulated and persistent in $\mathrm{CD}^{+}{ }^{+} \mathrm{T}$ cells recovered from inflamed tissues of patients with chronic inflammation (that is, rheumatic diseases, Crohn's disease and ulcerative colitis), despite therapeutic treatment. However, they did not definitely validate whether Twist 1 was a hallmark of $T_{H} 1$ rather than of $\mathrm{T}_{\mathrm{H}} 2$ or of $\mathrm{T}_{\mathrm{H}} 17$ polarization in humans (Table 1).

In summary, Twist1 expression in T cells considerably lowered their contribution to inflammation and tissue destruction in mice. Expression of Twist 1 in $T_{H} 1$ cells acts as an endogenous regulator limiting the proinflammatory potential of $\mathrm{T}_{\mathrm{H}} 1$ cells in the continuous presence of antigen with repeated activation of NFAT and NF- $\kappa B$. In humans, the specificity of Twist1 upregulation in $\mathrm{CD}^{+}{ }^{+} \mathrm{T}$ cells recovered under a chronic inflammation context lead the authors to propose that Twist1 could be used as a biomarker of chronic inflammation.

Pham et al. ${ }^{42}$ further defined the role of Twist 1 in $T_{H} 1$ cellmediated inflammation. They showed that Twist1 modulated inflammation, as measured by inhibition of IFN $\gamma$ production, by decreasing the expression of T-bet, STAT4 and RUNX3 and their binding to the IFN $\gamma$ locus. Of note, only RUNX3 overexpression was able to compensate for Twist1-mediated inhibition of IFN $\gamma$, and this was achieved through direct physical interaction with Twist1. The authors did not observe direct binding of Twist 1 to the promoter regions of IFN $\gamma, T N F \alpha$ and IL12R $\beta 2$. Interestingly, they showed that Twist 1 expression was not restricted to $T_{H} 1$ cells, but could also be measured in $\mathrm{T}_{\mathrm{H}} 2$ cells, although at a lower level.

In a subsequent study, the same group identified Twist1 as a key factor that hindered $T_{H} 17$ polarization. ${ }^{43}$ They showed that Twist 1 was a key component of a STAT3-induced feedback loop that controls IL6 signaling through inhibition of IL6R $\alpha$ to block $T_{H} 17$ and $\mathrm{TF}_{\mathrm{H}}$ cell development differentiation. Phenotypically, mice with a $T$ cell-specific deletion of Twist 1 also exhibited early-onset experimental autoimmune encephalomyelitis, and increased antigen-specific antibody responses, demonstrating a significant role for Twist1 in limiting both cellular and humoral immunity.

Twist2 and T lymphocytes. The function of Twist2 in T lymphocytes and immature thymocytes seems to focus mainly around the prevention of galectin-1-induced apoptosis, a process normally occurring after NF- $\mathrm{KB}$ activation during the negative selection in the thymus. This has been explored in two publications by Koh et al. ${ }^{19,32}$ in 2008 and 2009 (Table 1). CD7, a galectin-1 receptor, plays a crucial role in galectin-1-mediated apoptosis of activated T cells. E12 and Twist2 prevent NF-KB-mediated activation of the CD7 promoter. By doing so, they inhibit galectin-1-induced apoptosis in immature $\mathrm{T}$ cells. This targeted inhibition appears to be mediated by direct binding to the E-box in the CD7 promoter or through direct interaction with NF- $\mathrm{KB}$. In any case, both bHLH transcription factors significantly reduce binding of $\mathrm{NF}-\kappa \mathrm{B}$ to the CD7 promoter. ${ }^{19,32}$

These studies characterize Twist2 as a dangerous inhibitor of negative selection-mediated apoptosis. In this context, it is easily conceivable that Twist2 uncontrolled expression may lead to autoimmunity and/or T-cell oncogenesis.
B lymphocytes. The expression of Twist1-2 in normal B lymphocytes has been poorly described so far. Early evidence of their potential expression came from a study published in 2004 by Raval et al. ${ }^{44}$ that focused on of the twist $25^{\prime}$ upstream region and its consequence on expression in chronic lymphocytic leukemia (CLL) patients (see below). DNA methylation occurs in regions rich in CpG islands, typically in the $5^{\prime}$ upstream region of genes and results in condensation of the chromatin and downregulation of transcription. ${ }^{45}$ They showed that the twist2 promoter was not methylated in $\mathrm{CD}_{19}{ }^{+} \mathrm{B}$ cells purified from healthy controls and that Twist2 mRNA was indeed detected in these cells. In our hands, Twist 1-2 could be detected in B cells in response to several proinflammatory signals ( $\mathrm{N}$ Merindol, unpublished results). However, further studies are definitely needed to confirm the expression and possible functions of Twist1-2 in B cells.

\section{TWIST1-2 AS EMERGING RISK FACTORS IN HEMATOLOGICAL MALIGNANCIES}

The overexpression of Twist 1 has been described as a poor prognostic factor in numerous epithelium-derived malignancies such as breast cancer, prostate cancer, colorectal cancer, bladder cancer, melanoma, hepatocellular carcinoma and neck carcinoma (reviewed in Puisieux et $a l^{46}$ ). Twist1-2 deregulations have also been more recently detected in hematological malignancies. Their precise roles are ill-defined in this latter context, and probable mechanisms of their oncogenic properties must be extrapolated from results obtained in solid tumors that we briefly summarize below.

The central role of Twist1-2 in embryogenesis and mesodermal development and their targeting of multiple genes coding for cell-fate proteins inevitably links them to cancer and oncogenesis. In brief, Twist1 has been implicated in cancer initiation by counteracting both senescence and apoptosis programs and in cancer progression by increasing resistance to treatment.

In cancer cells where Twist 1 or Twist2 expression is increased, it has been demonstrated that they neutralize senescence and cell death through inhibition of both p53 and Rb tumor suppressor pathways ${ }^{47}$ (Figure 2). Interestingly, Twist1-2 E-boxes are found in the regulatory region of the cyclin-dependent kinase inhibitors p21, P15 (INK4B) and p16 that can induce cell cycle arrest upon DNA damage. Both Twist1-2 repress senescence by inhibiting the transcription of p53 target p21 and of p16. ${ }^{47}$ Furthermore, they inhibit the expression of p14ARF and perturb the p14ARF-MDM2p53 axis. $^{48}$ In fact, Twist1-2 are able to repress the p53 proapoptotic response at each step that may lead to its activation, through: (1) inhibition of transcriptional co-activators of p53, such as acetyltransferase p300,(2) prevention of p53 phosphorylation and (3) preclusion of p53 DNA-binding activity. ${ }^{14,49-51}$

Twist1 also offsets the apoptosis response induced by other pathways in addition to the DNA damage response. For example, Twist1 is able to block the c-Myc-induced apoptotic response through modulation of the p14ARF-MDM2-p53 pathway in in vitro experiments on mouse embryonic fibroblasts. ${ }^{48} \mathrm{~N}-\mathrm{Myc}$ expression is amplified in neuroblastomas accompanied by a systematic overexpression of Twist1. Prevention of apoptosis by Twist 1 in this context could be partly attributable to impaired p14ARF activity, once again through hindering of the p14ARFMDM2-p53 axis. ${ }^{51}$ As a direct consequence of their capacity to override oncogene-induced senescence and apoptosis, Twist1-2 cooperate in vitro and in vivo with mitogenic oncoproteins for malignant transformation ${ }^{46,49-51}$ (Figure 2).

In addition, Twist1-2 were recently shown to be involved in the direct regulation of microRNAs (such as miR-199a/214 and miR$10 \mathrm{~b}$ involved in breast cancer invasiveness) ${ }^{52}$ and of genes linked to cancer progression. ${ }^{53,54}$ Namely, Twist1 is able to bind to the promoter of the proto-oncogene AKT2 to upregulate its 


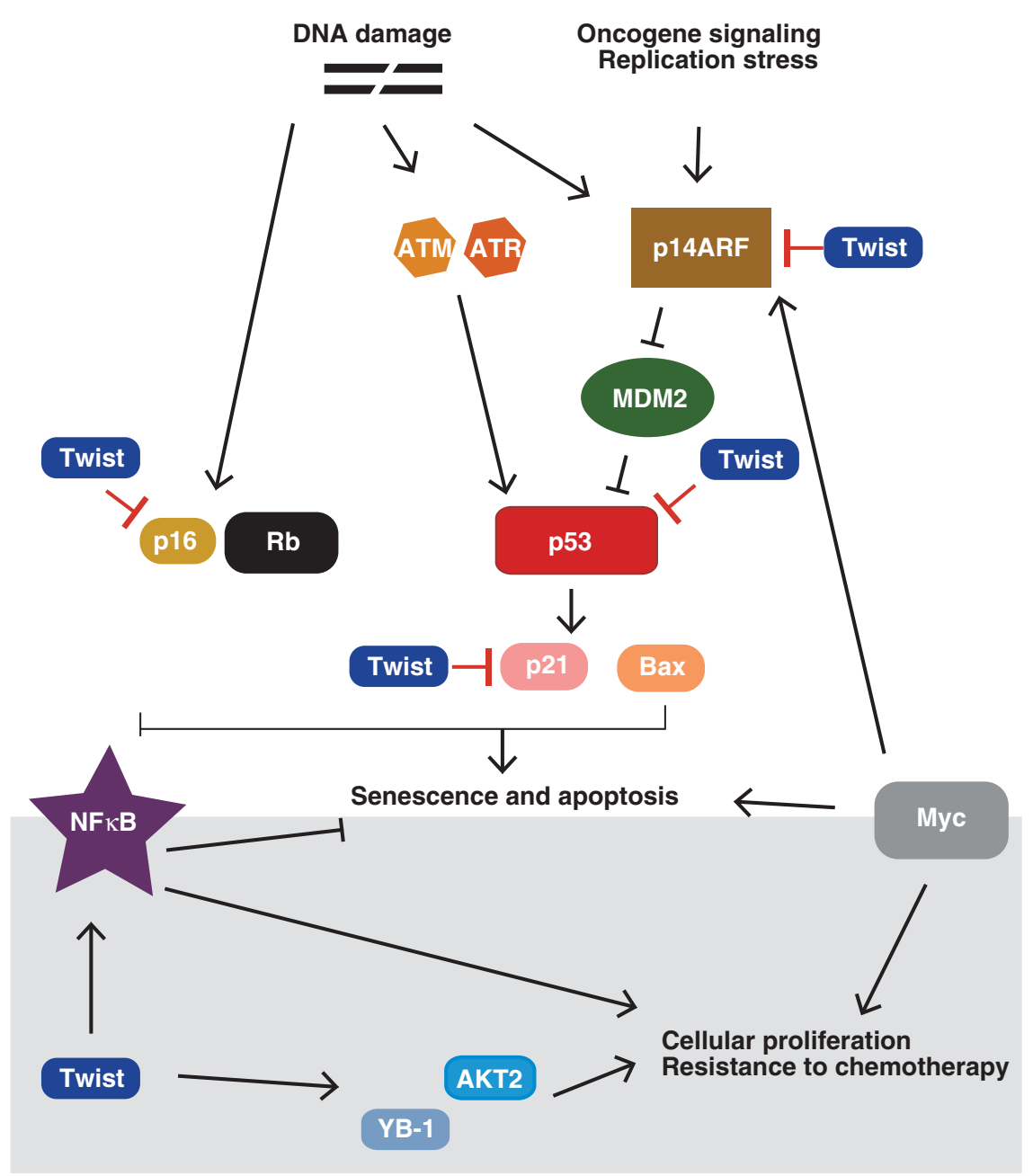

Figure 2. Targets of Twist proteins in the DNA damage response pathway. In healthy conditions, DNA damage triggers the activation of ataxia telangiectasia mutated (ATM) and ATR kinases that usually results in activation of p53, of its transcriptional targets cyclin-dependent kinase inhibitor p21 (CIP/WAF1, CDKN1A) and/or Bax, and ultimately leads to senescence or apoptosis. DNA damage can also induce the cyclindependent kinase inhibitor p16 (INK4A) and the tumor suppressor retinoblastoma (Rb) that will further stabilize senescence cell cycle arrest. p14ARF might also come into play during the DNA damage response and is additionally induced by cellular stresses such as oncogene signaling and replication stress. p14ARF is an upstream regulator of p53 that acts through repression of p53-inhibitor MDM2. Myc transcription factor family members promote cell growth and proliferation, but might at the same time induce p53-dependent (through p14ARF) and -independent apoptosis. In cancer cells where Twist1 or Twist2 expression is increased, they neutralize senescence and cell death through inhibition of both $\mathrm{p} 53$ and $\mathrm{Rb}$ tumor-suppressor pathways. Twist $1-2$ repress senescence through binding to E-boxes in the regulatory region of p21 and p16. They might also inhibit the expression of p14ARF. Furthermore, Twist1 is able to block the Myc-induced apoptotic response through modulation of the p14ARF-MDM2-p53 pathway. Conversely, they increase cellular proliferation and trigger resistance to chemotherapy through the upregulation of AKT2 and YB-1 and the activation of the antiapoptotic NF-KB response.

expression, and to activate the transcription factor Y-boxbinding protein 1 (YB-1) associated with cellular proliferation. Overexpression of YB-1 and AKT2 have been observed in several malignancies and linked to poor prognosis. ${ }^{53,54}$ In breast cancers, Twist1 oncogenic functions that promote EMT are controlled by its phosphorylation mediated by PKB/Akt, leading to modulation of TGF $\beta 2$ transcription and enhanced TGF $\beta$ receptor signaling. ${ }^{21}$

Twist1 expression is also connected to cancer cell resistance to chemotherapeutic agents, such as taxol and vincristine that target microtubules, and that are used in nasopharyngeal, bladder, ovarian and prostate cancers. ${ }^{53,55-57}$ This acquired resistance to apoptosis induced by chemotherapeutic drugs triggered by Twist1 is partly because of activation of the antiapoptotic NF- $\kappa B$ response. $^{58}$

Finally, Twist1-2 have also been implicated in metastasis formation through EMT, thereby facilitating cancer cell invasion. $^{41,59}$ Twist 1 induction of metastasis through EMT plays a central role in epithelium-based cancers but may not be the most relevant pathological effect in hematological malignancies, because they derive from cells with intrinsic motility capacity.

Twist 1-2 in malignancies derived from the myeloid lineage Myelodysplastic syndromes (MDS). MDS are clonal disorders of hematopoietic stem/precursor cells characterized by abnormal maturation and differentiation, an increasing resistance to proapoptotic signals and a high risk for MDS patients to progress to acute myeloid leukemia (AML).

Upregulation of TNF $\alpha$ is typically observed in MDS bone marrow (BM) and is associated with a decreased expression of Twist1 in stromal cells. ${ }^{60}$ In contrast, Twist 1 expression is augmented in the $\mathrm{CD} 4^{+}$hematopoietic stem cell compartment from MDS BMs. ${ }^{34}$ This increase in Twist1 expression appears to be induced in hematopoietic precursors by stroma contact and more frequent in 
advanced-stage compared with low-grade MDS. A physical interaction between endogenous Twist1 and p53 has been detected and associated with resistance to apoptosis through inhibition of proapoptotic protein Bax expression. ${ }^{34}$ Furthermore, forced inhibition of Twist1 in myeloid cell lines and primary $\mathrm{CD}_{4}{ }^{+}$MDS cells resulted in increased expression of p53 and Bax, and enhanced TNF $\alpha$-triggered apoptosis (Table 2). Li et al. ${ }^{34}$ also observed an inverse correlation between the protein levels of Twist 1 and p53 phosphorylated at serine 46. In 2013, the same group established that interactions between Twist1-dependent miR-10 family member and p53 played a central role in regulating TNF $\alpha$-mediated apoptosis in MDS clonal cells. ${ }^{61}$ They showed that miRs $10 \mathrm{a} / \mathrm{b}$ facilitated apoptotic responses and decreased cell proliferation through direct modulation of the $\mathrm{p} 53$ promoter and of downstream targets of NF- $\kappa \mathrm{B}$ after transcriptional activation by Twist1. Of note, Twist1 inhibition also increased apoptosis in cell lines displaying mutated p53, suggesting that Twist 1 contributes to additional pathways in the apoptotic response to stroma in MDS that have yet to be defined.

Acute myeloid leukemia. AML is characterized by a rapid growth and an increased number of myeloid-derived blast cells that accumulate in the BM, paired with an arrest in their maturation. This process interferes with hematopoiesis and frequently results in hematopoietic insufficiency.

$\mathrm{N}-\mathrm{Myc}$ overexpression is frequently detected in AML. ${ }^{62}$ Similar to observations made in neuroblastoma, experiments in mice showed that Twist1 is upregulated in AML-expressing $\mathrm{N}$-myc, therefore suggesting that Twist1-mediated disruption of the apoptotic response through the ARF/p53/MDM2 pathway could be involved in N-Myc-positive $\mathrm{AML}^{62}$ (Table 2). Furthermore, studies on the myeloid leukemic cell line U937 showed that Twist1 expression activated by the PKB/Akt/mTor (mammalian target of rapamycin) pathway through the neutrophin receptor TrkC (tropomyosin-related kinase C) molecular network (implicated in leukemogenesis) ${ }^{63}$ was involved in resistance to apoptosis, ${ }^{64}$ whereas when activated by Axl, Twist1 expression was implicated in resistance to treatment. ${ }^{65}$

Finally, plasma levels of TNF $\alpha$, IL6 and IL10 are increased in AML patients. ${ }^{66}$ IL6 level is inversely correlated to patient survival. IL6 signalization acts through STAT3/5 activation to promote survival in $\mathrm{AML}^{67}$ and, in theory, this may lead to the activation of Twist1-2 expression. Importantly, deregulation of Twist1-2 expression in AML patients remains to be demonstrated.

Table 2. Functions of Twist 1 and Twist 2 in hematological malignancies

\begin{tabular}{|c|c|c|}
\hline & Twist1 & Twist2 \\
\hline \multicolumn{3}{|l|}{ Myeloid malignancies } \\
\hline MDS & $\begin{array}{l}\text { - Expressed in } \mathrm{CD} 34^{+} \text {hematopoietic stem cells }{ }^{34} \text {; } \\
\text { Expression associated with disease stage } \\
\text { - Inhibition of apoptosis } \\
\text { Interaction with p53, and Bax inhibition } \\
\text { Regulation of TNF } \alpha \text {-mediated apoptosis }{ }^{34,61} \text { through miR-10. } \\
\text { Modulator of unknown p53-independent pathway of } \\
\text { apoptosis }\end{array}$ & NA \\
\hline AML & $\begin{array}{l}\text { - Upregulated in } \mathrm{N}-\mathrm{Myc}^{+} \mathrm{AML}^{62} ; \\
\text { - Possible implication in resistance to apoptosis } \\
\text { treatment }{ }^{65} \text { and to }\end{array}$ & $\begin{array}{l}\text { - Hypermethylation of twist2 promoter region in some } \\
\text { cases of childhood } \mathrm{AML}^{104} \\
\text { Function unknown }\end{array}$ \\
\hline CML & $\begin{array}{l}\text { - Increased expression }{ }^{35,68} \\
\text { - Associated with stage disease and treatment resistance. }\end{array}$ & - No hypermethylation of the twist2 promoter $^{104}$ \\
\hline \multicolumn{3}{|l|}{ T-cell lymphoma } \\
\hline $\mathrm{CTCL}$ & $\begin{array}{l}\text { - Highly expressed in } \mathrm{Sz}, \mathrm{MF} \text { and } \mathrm{CD} 30^{-} \mathrm{CTCL} \text {. } \\
\text { Correlated with MF and } \mathrm{Sz} \text { disease stage }{ }^{77,78} ; \\
\text { - Probable inhibition of apoptosis through association with } \\
\text { c-Myc and p53. }\end{array}$ & $\begin{array}{l}\text { - Highly expressed } \\
\text { - Antiapoptotic role }{ }^{81,82} \\
\text { Downregulation of CD7, galectin-1 receptor. }\end{array}$ \\
\hline $\mathrm{ALCL}$ & $\begin{array}{l}\text { - Highly expressed } \\
\text { Upregulated via STAT3 } \\
\text { - Probable role in invasiveness and chemoresistance linked to } \\
\text { phospho-Akt and Bmi-1 }\end{array}$ & NA \\
\hline \multicolumn{3}{|l|}{ B-cell lymphoma } \\
\hline $\begin{array}{l}\text { DLBCL, MzBCL, } \\
\mathrm{FL}\end{array}$ & $\begin{array}{l}\text { - Overexpressed in } \mathrm{DLBCL}_{1}^{99} \mathrm{MzBCL} \text { and } \mathrm{FL} \text { (unknown } \\
\text { function) (Merindol et al., this study, Figure 3a). }\end{array}$ & - Not overexpressed (Merindol et al., this study, Figure 3b). \\
\hline \multicolumn{3}{|l|}{ Leukemia } \\
\hline ALL & NA & $\begin{array}{l}\text { - Hypermethylation of twist } 2 \text { promoter region frequent in } \\
\text { childhood ALL. }{ }^{105} \\
\text { Associated with loss of Twist } 2 \text { expression } \\
\text { Loss associated with disease stage/relapse } \\
\text { - Tumor-suppressor properties } \\
\text { Loss of Twist2 linked to cell growth and to resistance to } \\
\text { apoptosis and chemotherapeutic agents. }\end{array}$ \\
\hline CLL & NA & $\begin{array}{l}\text { Frequent promoter region methylation in mutated Ig } \mathrm{V}_{\mathrm{H}} \\
\text { CLL subtypes } \\
\text { Associated with favorable prognosis. }{ }^{44}\end{array}$ \\
\hline
\end{tabular}

Abbreviations: $A L C L$, anaplastic large cell lymphoma; $A L L$, acute lymphoblastic leukemia; $A M L$, acute myeloid leukemia; $C L L$, chronic lymphocytic leukemia; Ig, immunoglobulin; CML, chronic myeloid leukemia; CTCL, cutaneous T-cell lymphoma; DLBCL, diffuse large B-cell lymphoma; $F L$, follicular lymphoma; MDS, myelodysplastic syndrome; MF, mycosis fungoides; MzBCL, marginal zone B-cell lymphoma; NA, not available; STAT, signal transducer and activator of transcription; Sz, Sézary syndrome; TNF, tumor necrosis factor; $V_{H}$, variable heavy chain. 
Chronic myelogenous or myeloid leukemia (CML). CML is a clonal stem cell disorder characterized by an increased number and unregulated growth of myeloid cells in the BM and accumulation of these cells in the blood. This disease is associated with a characteristic chromosomal translocation called the Philadelphia chromosome, consisting of a Bcr-Abl tyrosine kinase fusion.

In 2003, Tipping et al. ${ }^{68}$ detected the expression of Twist 1 in KCL22 CML cell lines in a genome-wide microarray analysis. Twist1 expression was further amplified in KCL22 clones that were resistant to Imatinib, a tyrosine kinase inhibitor (TKI). In 2010, Cosset et al. ${ }^{35}$ confirmed that Twist1 expression increased in $\mathrm{CD}_{4}{ }^{+}$hematopoietic stem cells and $\mathrm{CD}^{-}{ }^{-}$cells throughout CML disease progression. Its expression significantly decreased upon complete remission and increased again after relapse. Furthermore, they observed a 100-fold increase of Twist1 expression in TKI nonresponder compared with TKI responder samples (Table 2). The increase in Twist1 expression was specific to TKI-resistant patients in the $\mathrm{CD}_{3}{ }^{+}$cells compartment. Silencing of Twist1 by RNA interference experiments in cell lines decreased cell number and viability in response to Imatinib, whereas overexpression of Twist1 led to improved Imatinib resistance of previously sensitive cell lines. Therefore, Twist1 seems to be implicated in resistance to TKI in cell lines and the authors suggest that Twist 1 may be used as a novel predictive marker of TKI resistance in CML.

A recent study proposed a new role for Twist1 in CML. Xin et al. ${ }^{69}$ studied differences between the CML cell lines $\mathrm{K} 562$ and the multidrug-resistant K562/A02 derived by enrichment through treatment with doxorubicin. They showed that Twist 1 was highly expressed in the multidrug-resistant cell lines derived from K562. Moreover, twist1 knockdown decreased the expression of stem cell markers such as Oct4, Sox2 and Nanog in this multidrugresistant cell line, suggesting that, in addition to participating in chemoresistance, Twist1 is involved in maintaining tumorinitiating or cancer stemness properties.

\section{Twist1-2 in lymphoid lineage-derived malignancies}

\section{T-cell lymphoma}

Cutaneous T-cell lymphoma (CTCL). CTCLs are a group of lymphoproliferative disorders characterized by localization of neoplastic $T$ cells in the skin. Classical forms of CTCLs are plaque-type mycosis fungoides (MF) and Sézary syndrome (Sz). The link between MF and Sz remains controversial. Sz was described by Albert Sézary, it can arise de novo or evolve from MF and is considered a rare leukemic variant. Sz is characterized by erythroderma, peripheral lymphadenopathy and the presence of malignant $T$ cells that are $\mathrm{CD} 4{ }^{+} \mathrm{CD} 45 \mathrm{RO}^{+}$and $\mathrm{CD}^{-}{ }^{-} \mathrm{CD}_{26}{ }^{-}$in the skin, lymph nodes and peripheral blood, chronically activated and skewed toward $\mathrm{T}_{\mathrm{H}} 2$ differentiation. ${ }^{70}$ These $T$ cells are derived from the same T-cell clone. ${ }^{71} \mathrm{MF}$ is a slowly progressive disease ( $87 \%$ 5-year survival), whereas $\mathrm{Sz}$ is more aggressive with a poor prognosis (11\% 5-year survival). In both diseases, chemotherapy and BM transplantation are not curative and do not significantly improve survival.

Twist1. Sz and MF are defined by aberrations in four pathways: (1) evasion of activation-induced cell death, (2) $T_{H} 2$-biased lymphocyte differentiation, (3) TGF $\beta$ receptor expression and (4) modulation of TNF receptor ligands (reviewed in Dulmage et $a l^{70}$ ). Molecularly, typical observations of these diseases include the constitutive activation of STAT3 $3^{72,73}$ and NK-KB, ${ }^{74}$ decreased expression of TGF $\beta$ receptor II, of downstream modulators such as SMAD3/5 and of its ligand TGF $\beta 1,{ }^{75}$ diminished detection of $\mathrm{p} 15$ and $\mathrm{p}^{16^{76}}$ and dysregulation of the c-Myc and of TNF-associated pathways.

All these molecular alterations point toward a possible implication of Twist1. In 2004, van Doorn et al. ${ }^{77}$ first identified high overexpression of the tyrosine kinase receptor EphA4 and of the transcription factor Twist 1 in $\mathrm{Sz}^{78}$ (Table 2). Similar results were observed in a subset of patients with MF and with CD30-negative primary CTCL. Although they did not perform any mechanistic experiments, the authors proposed that Twist1 could block c-Mycinduced apoptosis by antagonizing the p53 pathway. In 2012, a study by Goswami et al. ${ }^{79}$ showed that Twist1 expression was indeed correlated with MF and Sz stages. Moreover, they observed an association between increased Twist 1 and c-Myc expression and abnormal p53 expression. The precise role of Twist 1 and of other Sz- and MF-specific upregulated proteins (that is, PLS3, KIR3DL2, NKp36) in CTCL remains to be characterized. ${ }^{80}$

Twist2. Similar to conclusions from experiments in primary $\mathrm{T}$ lymphocytes, studies by SH Koh et al. ${ }^{19,32}$ suggested that Twist2, like Twist1, plays an antiapoptotic role in T-cell lymphoma but through a distinct pathway (Table 2). Indeed, they showed that Twist2 was overexpressed in mature T-cell lymphoma cells and specifically highly expressed in Sz cells. Ectopic expression of Twist2 was able to downregulate the expression of the galectin-1 receptor CD7 through induction of chromatin deacetylation. This led to a decrease in galectin-1-mediated apoptosis in activated $\mathrm{T}$ cells that promoted malignant T-cell accumulation and progression of T-cell lymphoma. Accordingly, CD7 expression is dramatically downregulated in Sz and galectin-1-induced apoptosis by CD7 is inhibited. ${ }^{81,82}$

Of note, downregulation of CD7 is also related to the progression of adult T-cell lymphoma/leukemia where galectin-3-induced apoptosis is inhibited ${ }^{83}$ although Twist2 expression has not yet been detected in this context.

Anaplastic large cell lymphoma (ALCL). $\mathrm{ALK}^{+} \mathrm{ALCL}$ represents a small subset of non-Hodgkin's T-cell lymphoma characterized by a specific chromosomal translocation and the fusion of nucleophomin (NPM) and anaplastic large cell lymphoma kinase (ALK) genes in the majority of cases. This leads to ubiquitous expression of ALK, whose expression is normally restricted to the brain and nervous system. NPM-ALK promotes oncogenesis by activating cellular signaling proteins, including STAT3, MEK/ERK, mTOR and (PI3K)/Akt (reviewed in Amin et $a l^{84}$ and Chiarle et $a l^{85}$ ). The activation of these pathways has been linked to Twist 1 expression in other malignancies as well as to increased cell proliferation and resistance to apoptosis.

NPM-ALK promotes tyrosine phosphorylation of STAT2 on Y705, essential for dimerization and activation of STAT3. ${ }^{86}$ Inhibition of STAT3 leads to apoptosis and cell cycle arrest in $\mathrm{ALK}^{+} \mathrm{ALCL}$ cell lines and is required for its lymphomagenesis. ${ }^{87,88}$ In 2012, Zhang et al. ${ }^{89}$ reported that STAT3 directly upregulated Twist1 and that Twist1 was highly expressed in three ALK ${ }^{+} \mathrm{ALCL}$ cell lines and ex vivo in three $\mathrm{ALK}^{+} \mathrm{ALCL}$ tumor-derived samples (Table 2). They performed functional assays that suggested that Twist 1 contributes to the invasiveness of $\mathrm{ALK}^{+} \mathrm{ALCL}$. In two out of three cell lines, Twist1 was linked to expression of phospho-Akt and Bmi-1 and downregulation of p66Shc (a member of Src homology and collagen homology family). Twist1 knockdown resulted in increased sensitivity to the chemotherapeutic agent ALK inhibitor Crizotinib in those two cell lines. These results need to be confirmed on a larger population of patients. Nevertheless, they suggest a key role for Twist1 as a regulator of apoptosis and resistance to treatment in this T-cell malignancy.

In addition, an in vitro study by Degerman et al. ${ }^{90}$ hints at a role for Twist1 during spontaneous oncogenesis of two Nijmegen breakage syndrome T-cell cultures established following mitogenic stimulation in the presence of IL-2. Twist1 expression is strongly increased in cell lines undergoing immortalization and appears to be of significance for senescence bypass in $T$ cells.

\section{B-cell lymphoma}

Diffuse large B-cell lymphoma (DLBCL), marginal zone B-cell lymphoma and follicular lymphoma. DLBCL is the most common subtype of 
non-Hodgkin's lymphoma among adults with an overall survival at 5 years of $60 \%$. Marginal zone B-cell lymphoma and follicular lymphoma are two other types of B-cell lymphoma, the latter being the second most common non-Hodgkin's lymphoma.

DLBCL arises from normal B cells or from the transformation of other types of lymphoma and leukemia. The disease is characterized by an aggressive and rapidly growing tumor that can arise in any part of the body. DLBCL is heterogeneous and encompasses a diverse set of clinical presentations and diagnosis. With the help of gene expression profiling, DLBCL can be divided into germinal centre B-cell-like, activated B-cell-like and primary mediastinal B cell-like subgroups. ${ }^{91,92}$

The first suggestions of a possible Twist1 dysregulation came from genetic studies performed by Davis et al. ${ }^{93}$ showing that the NF-kB pathway was constitutively activated in activated B-cell-like and primary mediastinal B cell-like DLBCL. In addition, the expression of STAT3 and IL6 is frequently triggered in activated B-cell-like subtypes. ${ }^{94}$ c-Myc overexpression because of chromosomal rearrangement or translocation is observed in $\sim 10 \%$ of DLBCL (regardless of the subtype) and associated with poor prognosis. ${ }^{95-98}$

In 2012, Lemma et al. ${ }^{99}$ detected the expression of Twist1 in the nucleus of the majority of DLBCL samples (83/99) by immunohistochemical staining. Twist1 expression correlated with Slug and Zeb1 expression, two other transcription factors associated with EMT $^{99}$ (Table 2). Nevertheless, the expression of Twist1 could not be associated with any prognostic value. Interestingly, overexpression of YB-1, a known target of Twist1 implicated in cellular proliferation, has also been described and linked to poor prognosis and rituximab resistance in DLBCL samples. ${ }^{100,101}$

With the aim of investigating a possible role of Twist1-2 in B-cell lymphoma, we performed real-time Q-PCR on samples derived from Origene (Lymphoma cDNA Array II LYRT102, OriGene Technologies, Inc., Rockville, MD, USA) (Figure 3). A description of each sample is found at www.origene.com/assets/documents/ TissueScan/LYRT102.xls. As a positive control, an analysis of Twist1 expression from a sample of a patient with MF was included. Reference values used as healthy controls were obtained from six samples of lymph nodes and spleen containing $100 \%$ normal cells, originally part of the mRNA samples present on the LYRT102 plate. We detected an increased expression of Twist1 in DLBCL samples and also in follicular and marginal zone B-cell lymphomas samples (although results were statistically significant only for follicular and marginal zone B-cell lymphoma compared with spleen and lymph node controls of normal appearance; Figure 3a). Twist2 expression was positively correlated with Twist1 expression. Although a high expression of Twist2 was detected in some patients in all three types of lymphoma, no significant overexpression of Twist 2 could be measured compared with controls (Figure $3 b$ ).

In conclusion, Twist1 seems to be overexpressed in several types of B-cell lymphomas. Given its potential as a therapeutic target in other types of cancer, further investigations are needed to characterize its function and its regulation.

Leukemia. Although there are considerable data showing Twist1-2 oncogenic properties in T-cell lymphoma and in myeloid leukemia, publications on their implication in lymphoid leukemia remain sporadic and results remain to be confirmed.

Acute lymphoblastic leukemia (ALL). ALL is the most common type of leukemia in childhood and still accounts for $25 \%$ of all deaths from pediatric cancers. In adults, it is even more difficult to treat with a 5-year survival of $40 \%$. It can derive from both B lymphocytes and $T$ cells.

In several types of cancer such as leukemia, differences in biology and survival between patients may be due, in part, to inappropriate epigenetic regulation, such as silencing of tumor suppressor genes through DNA methylation. ${ }^{102,103}$

Preliminary evidence suggesting that Twist 2 might play a role in ALL came from observations of specific dysregulated pathways of transcription factors that are known targets of Twist2, namely RUNX1 (fused with ETV6 in $25 \%$ of childhood ALL) and NF- $\kappa$ B. $^{31}$ In 2012, Thathia et al. ${ }^{104}$ identified that hypermethylation of the twist2 promoter is frequent in both childhood (30 of 54 including 28 of 43 B-ALL and 2 of 7 T-ALL) and adult ALL (52 of 77 patients including 27 of 39 B-ALL and 13 of 15 T-ALL), whereas it was only moderately observed in childhood AML (4 of 28 cases) and rarely
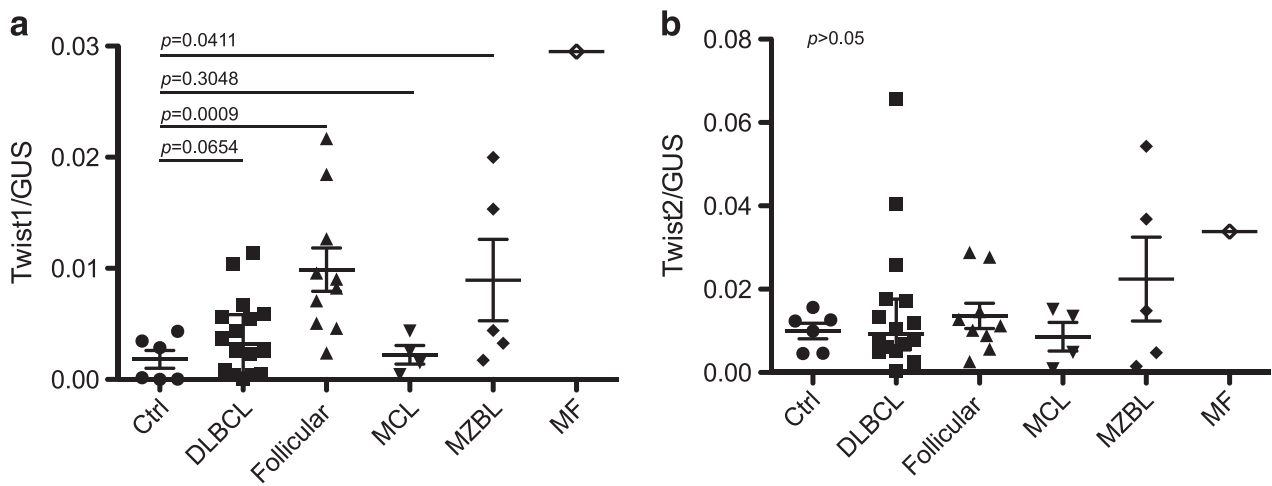

Figure 3. Twist1-2 mRNA levels in several types of non-Hodgkin's B-cell lymphomas. The mRNA levels of twist1 and twist2 were measured by real-time PCR using the Applied Biosystems StepOnePlus Realtime PCR systems (Life Technologies, Carlsbad, CA, USA) for 35 amplification rounds in Fast runs using the Fast SYBR Green Master mix (FastStart Universal SYBR Green Master, Roche, Basel, Switzerland). CTRL $(n=6)$, healthy control samples; DLBCL $(n=16)$, diffuse large B-cell lymphoma samples; follicular $(n=10)$, follicular lymphoma samples; MCL $(n=4)$, mantle cell lymphoma samples; MF $(n=1)$, mycosis fungoides sample; MZBC $(n=5)$, marginal zone B-cell lymphoma samples. Gus ( $\beta$-Glucuronidase) was the endogeneous control gene used to normalize DNA quantity. Relative expression was calculated as $2^{\text {(-(CTmean Twist10r2-CTmean Gus)) }}$. Statistics were performed independently between groups and control samples using the one-tailed Mann-Whitney $t$-test. (a) twist1 relative expression. twist 1 expression was significantly higher in follicular lymphoma and in marginal zone B-cell lymphoma. It was also higher in DLBCL, although it did not reach statistical significance. Of note, when comparisons were further separated in tissue-specific DLBCL samples, that is, that came either from spleen or from lymph nodes and compared with tissue-matched controls, results reached statistical significance $(P=0.0286$ between healthy and DLBCL samples derived from lymph nodes and $P=0.0357$ between healthy and DLBCL samples derived from spleen, data not shown). As twist1 expression is known to be upregulated in MF, one sample derived from a patient with MF was included as a positive reference value in the figure. (b) twist2 relative expression. twist2 expression was measured in the same samples as in Figure 1a. No statistically significant difference could be observed between groups. Of note, high variability was observed in DLBCL- and MZBL-derived samples. 
in CLL (5 of 110 cases). Noteworthy, Twist2 hypermethylation was not observed in CML and adult AML. Twist2 $5^{\prime}$ upstream regulatory region hypermethylation was more frequent in ETV6-RUNX1positive childhood ALL than in other childhood ALL cases (Table 2). Moreover, twist2 hypermethylation was especially frequent in relapsed adult ALL (20 of 22 cases), and the corresponding frequencies of samples exhibiting hypermethylated twist2 was higher following relapse than at the time of diagnosis. ${ }^{104}$

Hypermethylation resulted in loss of Twist2 expression in patient samples and ALL cell lines. Interestingly, restoration of Twist2 expression through transfection of Nalm6 and Reh ALL cell lines resulted in a dramatic inhibition of cell growth (aggravated by decamethasone treatment), associated with induction of apoptosis in ETV6-RUNX1 ${ }^{+}$Reh cell lines. ${ }^{104}$ The authors propose that Twist2 inhibition of cell growth could be mediated in some cases through inactivation of RUNX1 because the latter has been shown to increase proliferation and enhance B-cell survival ${ }^{105}$; although no experiments were conducted to test this. Finally, re-expression of Twist2 leads to an increased sensitivity to the chemotherapeutic agents etoposide and daunorubicin. The authors hypothesize that chemotherapeutic sensitivity modulation by Twist2 is mediated through NF-KB inhibition, because increased expression of the latter is correlated with chemoresistance.

In summary, in opposition to its role in T-cell lymphoma and in myeloid leukemia, Twist2 appears to exhibit tumor-suppressor properties in ALL.

Chronic lymphocytic leukemia. CLL is the most common type of leukemia, displaying a great variability with regard to clinical course and survival. It is characterized by slow and uncontrolled proliferation with disrupted apoptosis of a clonal B cell that results in the accumulation of cells and disruption of normal immune function. Prognostic factors associated with worsened survival include expression of ZAP70 and CD38, chromosomal aberrations (reviewed in Stilgenbauer et $\mathrm{al}^{106}$ ) and chromosomal deletions, ${ }^{107,108}$ p53 mutations ${ }^{109}$ and absence of somatic mutations in genes coding for immunoglobulin variable heavy chain $\left(\lg V_{H}\right){ }^{110,111}$ In addition, a high frequency of patients with unmutated Ig $V_{H}$ CLL exhibit p53 dysfunction.

DNA methylation is also implicated in the biology of CLL. ${ }^{112}$ In 2005, Raval et al. ${ }^{44}$ demonstrated that the Twist2 promoter was frequently methylated in patients exhibiting mutated $\lg V_{H}$ subtypes of CLL (associated with a favorable prognosis) but not in patients that exhibited unmutated $\lg \mathrm{V}_{\mathrm{H}}$ subtypes (associated with a poor prognosis) (Table 2). Methylation resulted in twist2 silencing in mutated subtypes, whereas Twist2 was expressed in unmutated subtypes. The authors suggest that the expression of Twist2 in unmutated Ig $\mathrm{V}_{\mathrm{H}}$ patients (with unmethylated twist2) could lead to disruption of the p53 pathway as observed in several other types of cancer, although they did not confirm this experimentally. In conclusion, parallel to what is seen in T-cell lymphoma but in opposition to observations in ALL, the expression of Twist2 in CLL could be associated with a poor prognosis.

\section{CONCLUSION AND PERSPECTIVES: OTHER BHLH PROTEINS IN HEMATOLOGICAL MALIGNANCIES}

Twist1-2-mediated gene expression modulation is intrinsically linked to the abundance of other bHLH members such as E2A and Id proteins. Interestingly, deregulation of expression of these proteins has been observed in various hematological malignancies. For instance, E2 ${ }^{\mathrm{ko}}$ mice display a high risk of developing T-cell tumors, as do $\mathrm{E} 2 \mathrm{~A}^{\mathrm{ko}} \mathrm{ld} 1^{\mathrm{ko}}$ mice. ${ }^{26} \mathrm{E} 47$ knockdown experiments in T-cell lymphoma cell lines linked E47 deficiencies to the development of T-cell malignancy. ${ }^{113}$ Loss of expression of $\mathrm{E} 2 \mathrm{~A}$, or its sequestration by Id2, has been linked to resistance to apoptosis in primary effusion lymphoma, ${ }^{114}$ to loss of B-cell phenotype and reprogramming of neoplastic B cells in Hodgkin's lymphoma. ${ }^{115}$ Id 1 is frequently overexpressed in various malignancies and its deregulated expression in mice has been associated with MDS development and immortalization of myeloid progenitors. ${ }^{116}$ In $\mathrm{AML}$, high expression of $\mathrm{Id} 1$ is implicated in leukemic cell proliferation and has been associated with poor prognosis. ${ }^{117}$ Id4 silencing is systematic in CLL and MDS and plays a role in its pathogenesis. ${ }^{118,119}$ In contrast, Id4 seems to act as an oncogene in B cell-derived malignancies such as ALL. ${ }^{120,121}$ Unfortunately, Twist1-2 function was not investigated in the studies mentioned herein.

In conclusion, numerous questions remain to be addressed concerning the role of Twist1-2 in hematological malignancies. There is still a disturbing paucity of data on Twist2 implication in blood malignancies and on the role of Twist1-2 in non-T-cell lymphoma/leukemia. As potential therapeutic targets and as central regulators of apoptosis and senescence, large efforts should be undertaken to promptly clarify the role of Twist1-2 and their partners in these types of cancer.

\section{CONFLICT OF INTEREST}

The authors declare no conflict of interest.

\section{ACKNOWLEDGEMENTS}

NM was supported by a fellowship from the ARC foundation (fondation ARC pour la recherche sur le cancer) and AR by a fellowship from the Ligue Nationale contre le Cancer. This work was supported by institutional grants from INSERM, Université de Lyon (to NB) and by a specific grant from the Cancéropole Grand Sud-Ouest (to NB).

\section{REFERENCES}

1 el Ghouzzi V, Le Merrer M, Perrin-Schmitt F, Lajeunie E, Benit P, Renier D et al. Mutations of the TWIST gene in the Saethre-Chotzen syndrome. Nat Genet 1997; 15: $42-46$.

2 Howard TD, Paznekas WA, Green ED, Chiang LC, Ma N, Ortiz de Luna Rl et al. Mutations in TWIST, a basic helix-loop-helix transcription factor, in SaethreChotzen syndrome. Nat Genet 1997; 15: 36-41

3 Hebrok M, Wertz K, Füchtbauer EM. M-twist is an inhibitor of muscle differentiation. Dev Biol 1994; 165: 537-544.

4 Lee YS, Lee HH, Park J, Yoo EJ, Glackin CA, Choi YI et al. Twist2, a novel ADD1/SREBP1C interacting protein, represses the transcriptional activity of ADD1/SREBP1c. Nucleic Acids Res 2003; 31: 7165-7174.

5 Spicer DB, Rhee J, Cheung WL, Lassar AB. Inhibition of myogenic bHLH and MEF2 transcription factors by the bHLH protein Twist. Science 1996; 272: $1476-1480$.

6 Murray SS, Glackin CA, Winters KA, Gazit D, Kahn AJ, Murray EJ. Expression of helix-loop-helix regulatory genes during differentiation of mouse osteoblastic cells. J Bone Miner Res 1992; 7: 1131-1138.

7 Tukel T, Šošić D, Al-Gazali LI, Erazo M, Casasnovas J, Franco HL et al. Homozygous nonsense mutations in TWIST2 cause Setleis syndrome. Am J Hum Genet 2010; 87: 289-296.

8 Sosic D, Richardson JA, Yu K, Ornitz DM, Olson EN. Twist regulates cytokine gene expression through a negative feedback loop that represses NF-kappaB activity. Cell 2003; 112: 169-180.

9 Thisse C, Perrin-Schmitt F, Stoetzel C, Thisse B. Sequence-specific transactivation of the Drosophila twist gene by the dorsal gene product. Cell 1991; 65: $1191-1201$.

10 Cheng GZ, Zhang WZ, Sun M, Wang Q, Coppola D, Mansour M et al. Twist is transcriptionally induced by activation of STAT3 and mediates STAT3 oncogenic function. J Biol Chem 2008; 283: 14665-14673.

11 Howe LR, Watanabe O, Leonard J, Brown AM. Twist is up-regulated in response to Wnt1 and inhibits mouse mammary cell differentiation. Cancer Res 2003; 63: 1906-1913.

12 Yang MH, Wu MZ, Chiou SH, Chen PM, Chang SY, Liu CJ et al. Direct regulation of TWIST by HIF-1alpha promotes metastasis. Nat Cell Biol 2008; 10: 295-305.

13 Gort EH, van Haaften G, Verlaan I, Groot AJ, Plasterk RH, Shvarts A et al. The TWIST1 oncogene is a direct target of hypoxia-inducible factor-2alpha. Oncogene 2008; 27: 1501-1510.

14 Hamamori Y, Sartorelli V, Ogryzko V, Puri PL, Wu HY, Wang JY et al. Regulation of histone acetyltransferases p300 and PCAF by the bHLH protein twist and adenoviral oncoprotein E1A. Cell 1999; 96: 405-413. 
15 Gong XQ, Li L. Dermo-1, a multifunctional basic helix-loop-helix protein represses MyoD transactivation via the HLH domain, MEF2 interaction, and chromatin deacetylation. J Biol Chem 2002; 277: 12310-12317.

16 Pan D, Fujimoto M, Lopes A, Wang YX. Twist-1 is a PPARdelta-inducible, negative-feedback regulator of PGC-1alpha in brown fat metabolism. Cell 2009; 137: $73-86$

17 Murre C, McCaw PS, Baltimore D. A new DNA binding and dimerization motif in immunoglobulin enhancer binding, daughterless, MyoD, and myc proteins. Cell 1989; 56: 777-783.

18 Bialek P, Kern B, Yang X, Schrock M, Sosic D, Hong N et al. A twist code determines the onset of osteoblast differentiation. Dev Cell 2004; 6: 423-435.

19 Koh HS, Lee C, Lee KS, Ham CS, Seong RH, Kim SS et al. CD7 expression and galectin-1-induced apoptosis of immature thymocytes are directly regulated by NF-kappaB upon T-cell activation. Biochem Biophys Res Commun 2008; 370: 149-153.

20 Hong J, Zhou J, Fu J, He T, Qin J, Wang L et al. Phosphorylation of serine 68 of Twist1 by MAPKs stabilizes Twist1 protein and promotes breast cancer cell invasiveness. Cancer Res 2011; 71: 3980-3990.

21 Xue G, Restuccia DF, Lan Q, Hynx D, Dirnhofer S, Hess D et al. Akt/PKBmediated phosphorylation of Twist1 promotes tumor metastasis via mediating cross-talk between PI3K/Akt and TGF- $\beta$ signaling axes. Cancer Discov 2012; 2: 248-259.

22 Firulli BA, Howard MJ, McDaid JR, Mcllreavey L, Dionne KM, Centonze VE et al. PKA, PKC, and the protein phosphatase $2 \mathrm{~A}$ influence HAND factor function a mechanism for tissue-specific transcriptional regulation. Mol Cell 2003; 12 $1225-1237$.

23 Firulli AB, Conway SJ. Phosphoregulation of Twist1 provides a mechanism of cell fate control. Curr Med Chem 2008; 15: 2641-2647. Review.

24 Vichalkovski A, Gresko E, Hess D, Restuccia DF, Hemmings BA. PKB/AKT phosphorylation of the transcription factor Twist-1 at Ser42 inhibits p53 activity in response to DNA damage. Oncogene 2010; 29: 3554-3565.

25 Castanon I, Von Stetina S, Kass J, Baylies MK. Dimerization partners determine the activity of the Twist bHLH protein during Drosophila mesoderm development. Development 2001; 128: 3145-3159.

26 Yan W, Young AZ, Soares VC, Kelley R, Benezra R, Zhuang Y. High incidence of T-cell tumors in E2A-null mice and E2A/ld1 double-knockout mice. Mol Cell Biol 1997: 17: 7317-7327.

27 Connerney J, Andreeva V, Leshem Y, Mercado MA, Dowell K, Yang X et al. Twist1 homodimers enhance FGF responsiveness of the cranial sutures and promote suture closure. Dev Biol 2008; 318: 323-334.

28 Benezra R, Davis RL, Lockshon D, Turner DL, Weintraub $\mathrm{H}$. The protein Id: a negative regulator of helix-loop-helix DNA binding proteins. Cell 1990; 61: 49-59.

29 Hayashi M, Nimura K, Kashiwagi K, Harada T, Takaoka K, Kato $\mathrm{H}$ et al. Comparative roles of Twist- 1 and $\mathrm{Id} 1$ in transcriptional regulation by BMP signaling. J Cell Sci 2007; 120: 1350-1357.

30 Danciu TE, Whitman M. Oxidative stress drives disulfide bond formation between basic helix-loop-helix transcription factors. J Cell Biochem 2010; 109: 417-424.

31 Sharabi $A B$, Aldrich $M$, Sosic $D$, Olson $E N$, Friedman $A D$, Lee $S H$ et al. Twist-2 controls myeloid lineage development and function. PLOS Biol 2008; 6: e316.

32 Koh HS, Lee C, Lee KS, Park EJ, Seong RH, Hong S et al. Twist2 regulates CD7 expression and galectin-1-induced apoptosis in mature T-cells. Mol Cells 2009; 28: $553-558$.

33 Sharif MN, Sosic D, Rothlin CV, Kelly E, Lemke G, Olson EN et al. Twist mediates suppression of inflammation by type I IFNs and Axl. J Exp Med 2006; 203 1891-1901

34 Li X, Marcondes AM, Gooley TA, Deeg HJ. The helix-loop-helix transcription factor TWIST is dysregulated in myelodysplastic syndromes. Blood 2010; 116 2304-2314.

35 Cosset E, Hamdan G, Jeanpierre S, Voeltzel T, Sagorny K, Hayette $S$ et al. Deregulation of TWIST-1 in the CD34 + compartment represents a novel prognostic factor in chronic myeloid leukemia. Blood 2011; 117: 1673-1676.

36 Wang SM, Coljee VW, Pignolo RJ, Rotenberg MO, Cristofalo VJ, Sierra F. Cloning of the human twist gene: its expression is retained in adult mesodermallyderived tissues. Gene 1997; 187: 83-92.

37 Mabbott NA, Kenneth Baillie J, Kobayashi A, Donaldson DS, Ohmori H, Yoon SO et al. Expression of mesenchyme-specific gene signatures by follicular dendritic cells: insights from the meta-analysis of microarray data from multiple mouse cell populations. Immunology 2011; 133: 482-498.

38 Appay V, van Lier RA, Sallusto F, Roederer M. Phenotype and function of human T lymphocyte subsets: consensus and issues. Cytometry A 2008; 73: 975-983. Review.

39 Wan YY. Multi-tasking of helper T cells. Immunology 2010; 130: 166-171. Review.
40 Niesner U, Albrecht I, Janke M, Doebis C, Loddenkemper C, Lexberg MH et al. Autoregulation of Th1-mediated inflammation by twist1. J Exp Med 2008; 205: 1889-1901.

41 Yang J, Mani SA, Donaher JL, Ramaswamy S, Itzykson RA, Come C et al. Twist, a master regulator of morphogenesis, plays an essential role in tumor metastasis. Cell 2004; 117: 927-939.

42 Pham D, Vincentz JW, Firulli $A B$, Kaplan MH. Twist1 regulates Ifng expression in Th1 cells by interfering with Runx3 function. J Immunol 2012; 189: 832-840.

43 Pham D, Walline CC, Hollister K, Dent AL, Blum JS, Firulli $A B$ et al. The transcription factor Twist1 limits $\mathrm{T}$ helper 17 and $\mathrm{T}$ follicular helper cell development by repressing the gene encoding the interleukin- 6 receptor $\alpha$ chain. J Biol Chem 2013; 288: 27423-27433.

44 Raval A, Lucas DM, Matkovic JJ, Bennett KL, Liyanarachchi S, Young DC et al. TWIST2 demonstrates differential methylation in immunoglobulin variable heavy chain mutated and unmutated chronic lymphocytic leukemia. J Clin Oncol 2005; 23: 3877-3885.

45 Nguyen CT, Gonzales FA, Jones PA. Altered chromatin structure associated with methylation-induced gene silencing in cancer cells: correlation of accessibility, methylation, MeCP2 binding and acetylation. Nucleic Acids Res 2001 29: 4598-4606

46 Puisieux A, Valsesia-Wittmann S, Ansieau S. A twist for survival and cancer progression. Br J Cancer 2006; 94: 13-17. Review.

47 Ansieau S, Bastid J, Doreau A, Morel AP, Bouchet BP, Thomas C et al. Induction of EMT by twist proteins as a collateral effect of tumor-promoting inactivation of premature senescence. Cancer Cell 2008; 14: 79-89.

48 Maestro R, Dei Tos AP, Hamamori Y, Krasnokutsky S, Sartorelli V, Kedes L et al. Twist is a potential oncogene that inhibits apoptosis. Genes Dev 1999; 13 2207-2217.

49 Stasinopoulos IA, Mironchik Y, Raman A, Wildes F, Winnard Jr P, Raman V. HOXA5-twist interaction alters p53 homeostasis in breast cancer cells. J Biol Chem 2005; 280: 2294-2299.

50 Shiota M, Izumi H, Onitsuka T, Miyamoto N, Kashiwagi E, Kidani A et al. Twist and p53 reciprocally regulate target genes via direct interaction. Oncogene 2008; 27: 5543-5553.

51 Valsesia-Wittmann S, Magdeleine M, Dupasquier S, Garin E, Jallas AC, Combaret V et al. Oncogenic cooperation between $\mathrm{H}$-Twist and N-Myc overrides failsafe programs in cancer cells. Cancer Cell 2004; 6: 625-630.

52 Haque I, Banerjee S, Mehta S, De A, Majumder M, Mayo MS et al. Cysteine-rich 61-connective tissue growth factor-nephroblastoma-overexpressed 5 (CCN5)/Wnt-1-induced signaling protein-2 (WISP-2) regulates microRNA-10b via hypoxia-inducible factor-1 $\alpha$-TWIST signaling networks in human breast cance cells. J Biol Chem 2011; 286: 43475-43485.

53 Cheng GZ, Chan J, Wang Q, Zhang W, Sun CD, Wang LH. Twist transcriptionally up-regulates AKT2 in breast cancer cells leading to increased migration, invasion, and resistance to paclitaxel. Cancer Res 2007; 67: 1979-1987.

54 Shiota M, Izumi H, Onitsuka T, Miyamoto N, Kashiwagi E, Kidani A et al. Twist pomotes tumor cell growth through YB-1 expression. Cancer Res 2008; 68 98-105.

55 Wang X, Ling MT, Guan XY, Tsao SW, Cheung HW, Lee DT et al. Identification of a novel function of TWIST, a bHLH protein, in the development of acquired taxol resistance in human cancer cells. Oncogene 2004; 23: 474-482.

56 Zhang X, Wang Q, Ling MT, Wong YC, Leung SC, Wang X. Anti-apoptotic role of TWIST and its association with Akt pathway in mediating taxol resistance in nasopharyngeal carcinoma cells. Int J Cancer 2007; 120: 1891-1898.

57 Zhan $X$, Feng $X$, Kong $Y$, Chen $Y$, Tan W. JNK signaling maintains the mesenchymal properties of multi-drug resistant human epidermoid carcinoma KB cells through snail and twist1. BMC Cancer 2013; 13: 180.

58 Pham CG, Bubici C, Zazzeroni F, Knabb JR, Papa S, Kuntzen C et al. Upregulation of Twist-1 by NF-kappaB blocks cytotoxicity induced by chemotherapeutic drugs. Mol Cell Biol 2007; 27: 3920-3935.

59 Thiery JP, Acloque H, Huang RY, Nieto MA. Epithelial-mesenchymal transitions in development and disease. Cell 2009; 139: 871-890. Review.

60 Stirewalt DL, Mhyre AJ, Marcondes M, Pogosova-Agadjanyan E, Abbasi N Radich JP et al. Tumour necrosis factor-induced gene expression in human marrow stroma: clues to the pathophysiology of MDS? Br J Haematol 2008; 140 444-453.

61 Li X, Xu F, Chang C, Byon J, Papayannopoulou T, Deeg HJ et al. Transcriptional regulation of miR-10a/b by TWIST-1 in myelodysplastic syndromes. Haematologica 2013; 98: 414-419.

62 Kawagoe $\mathrm{H}$, Kandilci A, Kranenburg TA, Grosveld GC. Overexpression of N-Myc rapidly causes acute myeloid leukemia in mice. Cancer Res 2007; 67 10677-10685.

63 Eguchi M, Eguchi-Ishimae M, Tojo A, Morishita K, Suzuki K, Sato $Y$ et al. Fusion of ETV6 to neurotrophin-3 receptor TRKC in acute myeloid leukemia with $\mathrm{t}(12 ; 15)(\mathrm{p} 13 ; \mathrm{q} 25)$. Blood 1999; 93: 1355-1363. 
64 Kim MS, Kim GM, Choi YJ, Kim HJ, Kim YJ, Jin W. TrkC promotes survival and growth of leukemia cells through Akt-mTOR-dependent up-regulation of PLK-1 and Twist-1. Mol Cells 2013; 36: 177-184.

65 Hong CC, Lay JD, Huang JS, Cheng AL, Tang JL, Lin MT et al. Receptor tyrosine kinase $A X L$ is induced by chemotherapy drugs and overexpression of $A X L$ confers drug resistance in acute myeloid leukemia. Cancer Lett 2008; 268: 314-324.

66 Sanchez-Correa B, Bergua JM, Campos C, Gayoso I, Arcos MJ, Bañas H et al. Cytokine profiles in acute myeloid leukemia patients at diagnosis: survival is inversely correlated with IL-6 and directly correlated with IL-10 levels. Cytokine 2013; 61: 885-891.

67 Redell MS, Ruiz MJ, Gerbing RB, Alonzo TA, Lange BJ, Tweardy DJ et al. FACS analysis of Stat $3 / 5$ signaling reveals sensitivity to G-CSF and IL- 6 as a significant prognostic factor in pediatric AML: a Children's Oncology Group report. Blood 2013; 121: 1083-1093.

68 Tipping AJ, Deininger MW, Goldman JM, Melo JV. Comparative gene expression profile of chronic myeloid leukemia cells innately resistant to imatinib mesylate. Exp Hematol 2003; 31: 1073-1080.

69 Xin H, Kong Y, Jiang X, Wang K, Qin X, Miao ZH et al. Multi-drug-resistant cells enriched from chronic myeloid leukemia cells by Doxorubicin possess tumorinitiating-cell properties. J Pharmacol Sci 2013; 122: 299-304.

70 Dulmage BO, Geskin LJ. Lessons learned from gene expression profiling of cutaneous T-cell lymphoma. Br J Dermatol 2013; 169: 1188-1197. Review.

71 Dippel E, Assaf C, Hummel M, Schrag HJ, Stein H, Goerdt S et al. Clonal T-cell receptor gamma-chain gene rearrangement by PCR-based GeneScan analysis in advanced cutaneous T-cell lymphoma: a critical evaluation. J Pathol 1999; 188: 146-154.

72 Eriksen KW, Kaltoft K, Mikkelsen G, Nielsen M, Zhang Q, Geisler C et al. Constitutive STAT3-activation in Sezary syndrome: tyrphostin AG490 inhibits STAT3-activation, interleukin-2 receptor expression and growth of leukemic Sezary cells. Leukemia 2001; 15: 787-793.

73 Zhang Q, Nowak I, Vonderheid EC, Rook AH, Kadin ME, Nowell PC et al. Activation of Jak/STAT proteins involved in signal transduction pathway mediated by receptor for interleukin 2 in malignant $\mathrm{T}$ lymphocytes derived from cutaneous anaplastic large T-cell lymphoma and Sezary syndrome. Proc Natl Acad Sci USA 1996; 93: 9148-9153.

74 Izban KF, Ergin M, Qin JZ, Martinez RL, Pooley RJ JR, Saeed S et al. Constitutive expression of NF-kappa B is a characteristic feature of mycosis fungoides: implications for apoptosis resistance and pathogenesis. Hum Pathol 2000; 31: 1482-1490.

75 Kadin ME, Cavaille-Coll MW, Gertz R, Massagué J, Cheifetz S, George D. Loss of receptors for transforming growth factor beta in human T-cell malignancies. Proc Natl Acad Sci USA 1994; 91: 6002-6006.

76 Scarisbrick JJ, Woolford AJ, Calonje E, Photiou A, Ferreira S, Orchard G et al. Frequent abnormalities of the p15 and p16 genes in mycosis fungoides and Sezary syndrome. J Invest Dermatol 2002; 118: 493-499.

77 van Doorn R, Dijkman R, Vermeer MH, Out-Luiting JJ, van der Raaij-Helmer EM, Willemze $\mathrm{R}$ et al. Aberrant expression of the tyrosine kinase receptor EphA4 and the transcription factor twist in Sézary syndrome identified by gene expression analysis. Cancer Res 2004; 64: 5578-5586.

$78 \mathrm{Ni}$ X, Richmond HM, Liao XM, Decker WK, Shiue LH, Shpall EJ et al. Induction of T-cell responses against cutaneous T-cell lymphomas ex vivo by autologous dendritic cells transfected with amplified tumor mRNA. J Invest Dermatol 2008; 128: $2631-2639$

79 Goswami M, Duvic M, Dougherty A, Ni X. Increased Twist expression in advanced stage of mycosis fungoides and Sézary syndrome. J Cutan Pathol 2012; 39: 500-507.

80 Michel L, Jean-Louis F, Begue E, Bensussan A, Bagot M. Use of PLS3, Twist, CD158k/KIR3DL2, and NKp46 gene expression combination for reliable Sézary syndrome diagnosis. Blood 2013; 121: 1477-1478.

81 Pace KE, Hahn HP, Pang M, Nguyen JT, Baum LG. CD7 delivers a pro-apoptotic signal during galectin-1-induced T cell death. J Immunol 2000; 165: 2331-2334.

82 Rappl G, Abken H, Muche JM, Sterry W, Tilgen W, André S et al. CD4 + CD7leukemic $T$ cells from patients with Sézary syndrome are protected from galectin-1-triggered T cell death. Leukemia 2002; 16: 840-845.

83 Liu TY, Chen CY, Tien HF, Lin CW. Loss of CD7, independent of galectin-3 expression, implies a worse prognosis in adult T-cell leukaemia/lymphoma. Histopathology 2009; 54: 214-220.

84 Amin HM, Lai R. Pathobiology of ALK + anaplastic large-cell lymphoma. Blood 2007; 110: 2259-2267. Review.

85 Chiarle R, Voena C, Ambrogio C, Piva R, Inghirami G. The anaplastic lymphoma kinase in the pathogenesis of cancer. Nat Rev Cancer 2008; 8: 11-23. Review.

86 Zamo A, Chiarle R, Piva R, Howes J, Fan Y, Chilosi M et al. Anaplastic lymphoma kinase (ALK) activates Stat3 and protects hematopoietic cells from cell death. Oncogene 2002; 21: 1038-1047.
87 Amin HM, McDonnell TJ, Ma Y, Lin Q, Fujio Y, Kunisada K et al. Selective inhibition of STAT3 induces apoptosis and G(1) cell cycle arrest in ALK-positive anaplastic large cell lymphoma. Oncogene 2004; 23: 5426-5434.

88 Chiarle R, Simmons WJ, Cai H, Dhall G, Zamo A, Raz R et al. Stat3 is required for ALK-mediated lymphomagenesis and provides a possible therapeutic target. Nat Med 2005; 11: 623-629.

89 Zhang J, Wang P, Wu F, Li M, Sharon D, Ingham RJ et al. Aberrant expression of the transcriptional factor Twist1 promotes invasiveness in ALK-positive anaplastic large cell lymphoma. Cell Signal. 2012; 24: 852-858.

90 Degerman S, Siwicki JK, Osterman P, Lafferty-Whyte K, Keith WN, Roos G. Telomerase upregulation is a postcrisis event during senescence bypass and immortalization of two Nijmegen breakage syndrome T cell cultures. Aging Cell 2010; 9: 220-235.

91 Alizadeh AA, Eisen MB, Davis RE, Ma C, Lossos IS, Rosenwald A et al. Distinct types of diffuse large B-cell lymphoma identified by gene expression profiling. Nature 2000; 403: 503-511.

92 Wright G, Tan B, Rosenwald A, Hurt EH, Wiestner A, Staudt LM. A gene expression-based method to diagnose clinically distinct subgroups of diffuse large B cell lymphoma. Proc Natl Acad Sci USA 2003; 100: 9991-9996.

93 Davis RE, Brown KD, Siebenlist U, Staudt LM. Constitutive nuclear factor kappaB activity is required for survival of activated B cell-like diffuse large B cell lymphoma cells. J Exp Med 2001; 194: 1861-1874.

94 Lam LT, Wright G, Davis RE, Lenz G, Farinha P, Dang L et al. Cooperative signaling through the signal transducer and activator of transcription 3 and nuclear factor\{kappa\}B pathways in subtypes of diffuse large B-cell lymphoma. Blood 2008; 111: 3701-3713.

95 Barrans S, Crouch S, Smith A, Turner K, Owen R, Patmore R et al. Rearrangement of MYC is associated with poor prognosis in patients with diffuse large B-cell lymphoma treated in the era of rituximab. J Clin Oncol 2010; 28: 3360-3365

96 Klapper W, Stoecklein H, Zeynalova S, Ott G, Kosari F, Rosenwald A et al. Structural aberrations affecting the MYC locus indicate a poor prognosis independent of clinical risk factors in diffuse large B-cell lymphomas treated within randomized trials of the German High-Grade Non-Hodgkin's Lymphoma Study Group (DSHNHL). Leukemia 2008; 22: 2226-2229.

97 Niitsu N, Okamoto M, Miura I, Hirano M. Clinical significance of 8q24/c-MYC translocation in diffuse large B-cell lymphoma. Cancer Sci 2008; 100: 233-237.

98 Savage KJ, Johnson NA, Ben-Neriah S, Connors JM, Sehn LH, Farinha P et al. MYC gene rearrangements are associated with a poor prognosis in diffuse large B-cell lymphoma patients treated with R-CHOP chemotherapy. Blood 2009; 114: 3533-3537.

99 Lemma S, Karihtala P, Haapasaari KM, Jantunen E, Soini Y, Bloigu R et al. Biological roles and prognostic values of the epithelial-mesenchymal transitionmediating transcription factors Twist, ZEB1 and Slug in diffuse large B-cell lymphoma. Histopathology 2013; 62: 326-333.

100 Hanzawa K, Momose S, Higashi M, Tokuhira M, Watanabe R, Kajino K et al. Y-box binding protein-1 expression in diffuse large B-cell lymphoma: an impact on prognosis in the rituximab era. Leuk Lymphoma 2010; 51: 2054-2062.

101 Xu W, Zhou L, Qin R, Tang H, Shen H. Nuclear expression of YB-1 in diffuse large B-cell lymphoma: correlation with disease activity and patient outcome. Eur J Haematol 2009; 83: 313-319.

102 Cameron EE, Baylin SB, Herman JG. p15(INK4B) CpG island methylation in primary acute leukemia is heterogeneous and suggests density as a critical factor for transcriptional silencing. Blood 1999; 94: 2445-2451.

103 Melki JR, Vincent PC, Brown RD, Clark SJ. Hypermethylation of E-cadherin in leukemia. Blood 2000; 95: 3208-3213.

104 Thathia SH, Ferguson S, Gautrey HE, van Otterdijk SD, Hili M, Rand V et al. Epigenetic inactivation of TWIST2 in acute lymphoblastic leukemia modulates proliferation, cell survival and chemosensitivity. Haematologica 2012; 97: 371-378.

105 Blyth K, Slater N, Hanlon L, Bell M, Mackay N, Stewart M et al. Runx1 promotes B-cell survival and lymphoma development. Blood Cells Mol Dis 2009; 43: 12-19.

106 Stilgenbauer S, Bullinger L, Lichter P, Döhner H. German CLL Study Group (GCLLSG) Chronic lymphocytic leukemia. Genetics of chronic lymphocytic leukemia: genomic aberrations and $\mathrm{V}(\mathrm{H})$ gene mutation status in pathogenesis and clinical course. Leukemia 2002; 16: 993-1007. Review.

107 Döhner H, Fischer K, Bentz M, Hansen K, Benner A, Cabot G et al. p53 gene deletion predicts for poor survival and non-response to therapy with purine analogs in chronic B-cell leukemias. Blood 1995; 85: 1580-1589.

108 Stankovic T, Weber P, Stewart G, Bedenham T, Murray J, Byrd PJ et al. Inactivation of ataxia telangiectasia mutated gene in B-cell chronic lymphocytic leukaemia. Lancet 1999; 353: 26-29. 
109 Lin K, Manocha S, Harris RJ, Matrai Z, Sherrington PD, Pettitt AR. High frequency of p53 dysfunction and low level of $\mathrm{VH}$ mutation in chronic lymphocytic leukemia patients using the VH3-21 gene segment. Blood 2003; 102: 1145-1146.

110 Damle RN, Wasil T, Fais F, Ghiotto F, Valetto A, Allen SL et al. Ig V gene mutation status and CD38 expression as novel prognostic indicators in chronic lymphocytic leukemia. Blood 1999; 94: 1840-1847.

111 Hamblin TJ, Davis Z, Gardiner A, Oscier DG, Stevenson FK. Unmutated Ig V(H) genes are associated with a more aggressive form of chronic lymphocytic leukemia. Blood 1999; 94: 1848-1854.

112 Rush LJ, Raval A, Funchain P, Johnson AJ, Smith L, Lucas DM et al. Epigenetic profiling in chronic lymphocytic leukemia reveals novel methylation targets. Cancer Res 2004; 64: 2424-2433.

113 Schwartz R, Engel I, Fallahi-Sichani M, Petrie HT, Murre C. Gene expression patterns define novel roles for E47 in cell cycle progression, cytokine-mediated signaling and T lineage development. Proc Natl Acad Sci USA 2006; 103: 9976-9981.

114 Lietz A, Janz M, Sigvardsson M, Jundt F, Dörken B, Mathas S. Loss of bHLH transcription factor $\mathrm{E} 2 \mathrm{~A}$ activity in primary effusion lymphoma confers resistance to apoptosis. Br J Haematol 2007; 137: 342-348.

115 Mathas S, Janz M, Hummel F, Hummel M, Wollert-Wulf B, Lusatis S et al. Intrinsic inhibition of transcription factor E2A by HLH proteins $A B F-1$ and Id 2 mediates reprogramming of neoplastic B cells in Hodgkin lymphoma. Nat Immunol 2006 7: 207-215.

116 Suh HC, Leeanansaksiri W, Ji M, Klarmann KD, Renn K, Gooya J et al. Id1 immortalizes hematopoietic progenitors in vitro and promotes a myeloproliferative disease in vivo. Oncogene 2008; 27: 5612-5623.
$117 \mathrm{Yu}$ WP, Scott SA, Dong WF. Induction of ID1 expression and apoptosis by the histone deacetylase inhibitor (trichostatin A) in human acute myeloid leukaemic cells. Cell Prolif 2008; 41: 86-97.

118 Chen SS, Claus R, Lucas DM, Yu L, Qian J, Ruppert AS et al. Silencing of the inhibitor of DNA binding protein 4 (ID4) contributes to the pathogenesis of mouse and human CLL. Blood 2011; 117: 862-871.

119 Wang H, Wang XQ, Xu XP, Lin GW. ID4 methylation predicts high risk of leukemic transformation in patients with myelodysplastic syndrome. Leuk Res 2010; 34: 598-604.

120 Bellido M, Aventín A, Lasa A, Estivill C, Carnicer MJ, Pons C et al Id4 is deregulated by a $\mathrm{t}(6 ; 14)(\mathrm{p} 22 ; \mathrm{q} 32)$ chromosomal translocation in a B-cell lineage acute lymphoblastic leukemia. Haematologica 2003; 88: 994-1001.

$121 \mathrm{Yu}$ L, Liu C, Vandeusen J, Becknell B, Dai Z, Wu YZ et al. Global assessment of promoter methylation in a mouse model of cancer identifies ID4 as a putative tumor-suppressor gene in human leukemia. Nat Genet 2005; 37: 265-274.

(i) This work is licensed under a Creative Commons Attributioncc) NonCommercial-ShareAlike 3.0 Unported License. The images or other third party material in this article are included in the article's Creative Commons license, unless indicated otherwise in the credit line; if the material is not included under the Creative Commons license, users will need to obtain permission from the license holder to reproduce the material. To view a copy of this license, visit http:// creativecommons.org/licenses/by-nc-sa/3.0/ 